\title{
Vocational High School Readiness in Anticipating 21st Century Environmental Turbulence
}

\author{
Bayu Rahmat Setiadi ${ }^{1}$, Sugiyono Sugiyono ${ }^{1}$, Thomas Sukardi ${ }^{1}$ \\ ${ }^{1}$ Faculty of Engineering, Universitas Negeri Yogyakarta, Yogyakarta, Indonesia
}

\begin{abstract}
This research aims to measure the readiness of VHS in Indonesia in facing 21st Century environmental turbulence by comparing the status and accreditation of schools. A total of 884 VHSs distributed in 34 provinces in Indonesia were involved as research respondents. As a result, VHS readiness in dealing with the phenomenon of turbulence is in the quite prepared category. From a school status perspective, public VHS is better prepared than private, and A-accredited VHS is better prepared than non-A accreditation. This research is useful to provide information to vocational education principals in Indonesia to anticipate environmental turbulence in organisation.
\end{abstract}

Keywords - environmental turbulence, vocational high school.

\section{Introduction}

The environmental turbulence of Vocational High Schools (VHS) in Indonesia can change continuously, substantially, uncertainly, unpredictably [1]. Rhenald Kasali called it a technological disruption for individuals who could not keep up with the times [2].

DOI: 10.18421/TEM104-57

https://doi.org/10.18421/TEM104-57

Corresponding author: Bayu Rahmat Setiadi, Faculty of Engineering, Universitas Negeri Yogyakarta, Yogyakarta, Indonesia.

Email: bayursetiadi@uny.ac.id

Received: 14 July 2021.

Revised: 09 November 2021.

Accepted: 16 November 2021.

Published: 26 November 2021.

(cc)BY-NC-ND (C) 2021 Bayu Rahmat Setiadi, Sugiyono Sugiyono \& Thomas Sukardi; published by UIKTEN. This work is licensed under the Creative Commons AttributionNonCommercial-NoDerivs 4.0 License.

The article is published with Open Access at www.temjournal.com
There are unique characteristics of turbulence that are identified such as change, uncertainty, and radicals [3]. The environment is considered to be very turbulent which can change and is complex, characterized by 1) increasing the novelty of change, 2) increasing the intensity of the environment, 3) increasing the speed of change; and 4) environmental complexity [4]. VHS has to have strong capabilities to survive adaptively and struggle to penetrate environmental turbulence wherever and whenever. Like an environment, turbulence needs to be adequately managed to be an anti-virus ecosystem that protects the environment [5]. VHS has a severe challenge when it has to meet the needs of current and future workforce [6]. Industry labor profiles that are difficult to predict cause the direction and vision of schools to follow the changing times.

The 21st Century is an era of VHS towards comprehensive governance development. Some shifts in learning systems can be seen from the inclusion of learning with a scientific approach, $4 \mathrm{C}$ 's approach (creativity, critical thinking skills, collaboration, and communication), teaching factory, internet of things, learning-oriented to Science, Technology, Engineering, Arts, and Mathematics (STEAM ), and the development of vocational laboratories [7]. Changes in teaching models have an impact on the output of vocational school graduates [8]. A rapid change encourages VHS to observe the balance of organizational performance [9] routinely. Inappropriate governance can lead to underdevelopment in times of change, disruption, ineffective and inefficient management, and outputs that are not by needs [10]. For this reason, the Directorate of VHS Development (DVHSD) recommends that schools implement Good-School Governance (GSG) in the face of 21st Century environmental turbulence [11]. GSG is like a defense firewall against all kinds of turbulence attacks from competitiveness, markets, policies, and technology.

One of the actions in anticipating environmental turbulence is through the analysis of management capability profiles [12], [13]. It is crucial to know in order to prevent any changes in environmental 
turbulence by using appropriate strategies through the identification of school-based management capability profiles. There are five environmental turbulence scales [13] as follows.

- Level 1 is a repetitive determination of market place based on historical, so at this level, the work is more repetitive.

- Level 2 is expanding at this level, changes occur incrementally, and very slowly, the measure of success of this change is based on the response of competitors' movements only.

- Level 3 is changing, changes that occur quickly based on extrapolation, where services are based on customer needs only.

- Level 4 is discontinuous, at this level, the change is discontinuous but predictable.

- Level 5 is surprising; at end level, changes are speedy and challenging to predict.

Various kinds of turbulence in markets, policies, technology and competitiveness have various shocks. Equivalent, each VHS in the Indonesian province has a diversity of acceptability. This study aims to explore the readiness of VHS in the face of environmental turbulence in the 21st Century nationally. This research can be a reference for vocational education managers in opening up global insights that challenges and threats need to be prepared and anticipated so that they are more ready to fight environmental turbulence. However, environmental turbulence can be attacked but cannot be avoided, so it needs to be prepared for strategic steps to attack the future.

\section{Commencement}

This quantitative research method uses a massive exploratory survey [14]. The survey is targeted at VHS school principals in Indonesia. The instrument is based on rubrics so that the questions are only 16 questions. Each item needs complex and continuous answers. The instrument went through a validation phase by management experts, vocational education, and policy. DVHSD also reviewed the instrument. A total of 884 respondents contributed to the filling of the scattered instruments through the survey-monkey application. Research instrument in the form of a questionnaire using a choice of answers on a Likert scale that is very easy, easy, hard, and very hard. The amount of data distribution in the research respondents is as follows.

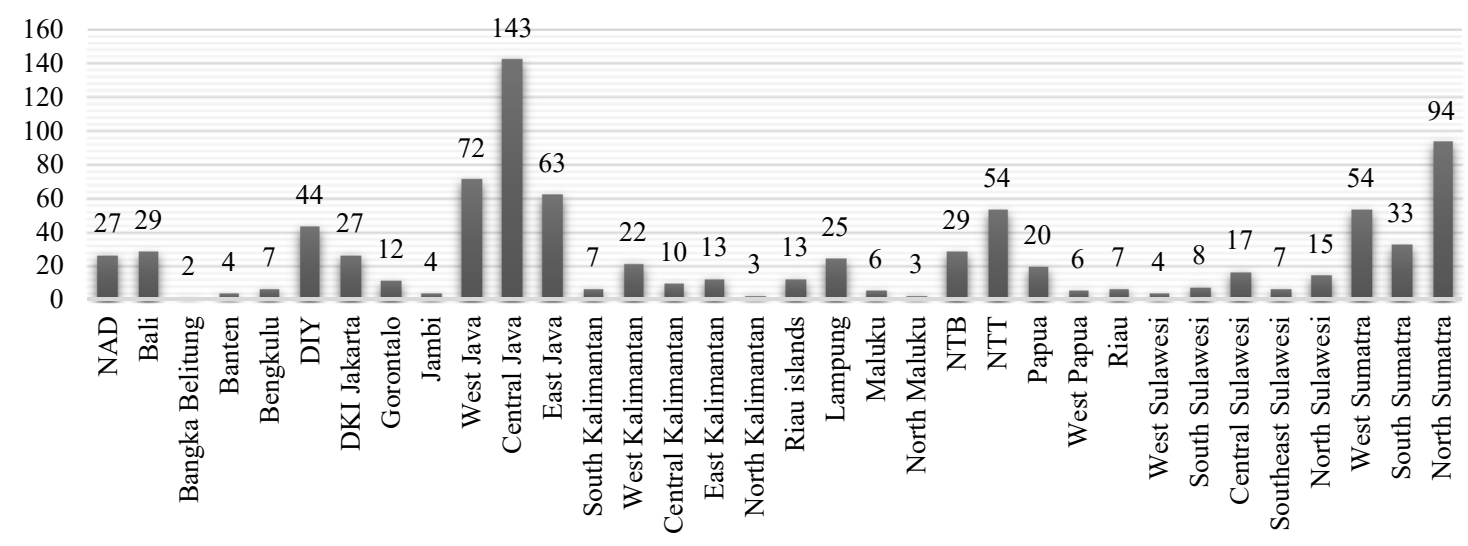

Figure 1. Distribution of Research Respondents

Based on the information in Figure 1, most respondents are Central Java. The high number of respondents was due to the highest number of VHSs in Indonesia in Central Java. Correspondingly, as many as $64.59 \%$ of principals responded to fill in the instrument, and the remaining percentage were teachers and vice-principals. Based on school status, data shows that $59.95 \%$ are filled by public schools, and the rest are private schools. Also, as much as Aaccredited schools and the rest filled $42.08 \%$ was filled by non-A accredited. Data analysis techniques used descriptive statistics. A simple explanation through the results of the survey with the presentation in the graph, the mean, and the percentage.

\section{Results and Discussion}

The 21st Century environmental turbulence survey was conducted in all VHS provinces in Indonesia. The survey was used to identify the extent to which vocational schools in Indonesia faced 21 st Century environmental turbulence by the perceptions and conditions of VHS. This study reviews the national condition of VHS in facing turbulence, comparison of State and Private VHS, and national VHS accreditation. Besides, the results of the study also explained comprehensively the turbulence that occurred in each province. 


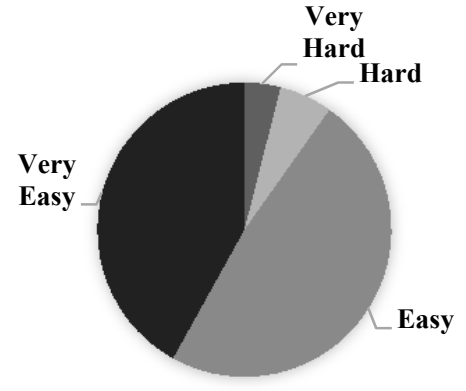

Figure 2. National VHS Readiness in Facing 21st Century Environmental Turbulence
Based on the pie chart in Figure 2, it shows that more than $50 \%$ of VHS respondents in Indonesia said they were ready, and the rest were doubtful about environmental turbulence. Descriptive qualitatively show that $63.99 \%$ VHS in Indonesia is strong enough to face environmental turbulence in the 21 st Century, both policy turbulence, technology turbulence, market turbulence, and competitiveness turbulence. The distribution of turbulence between provinces is as follows.

80

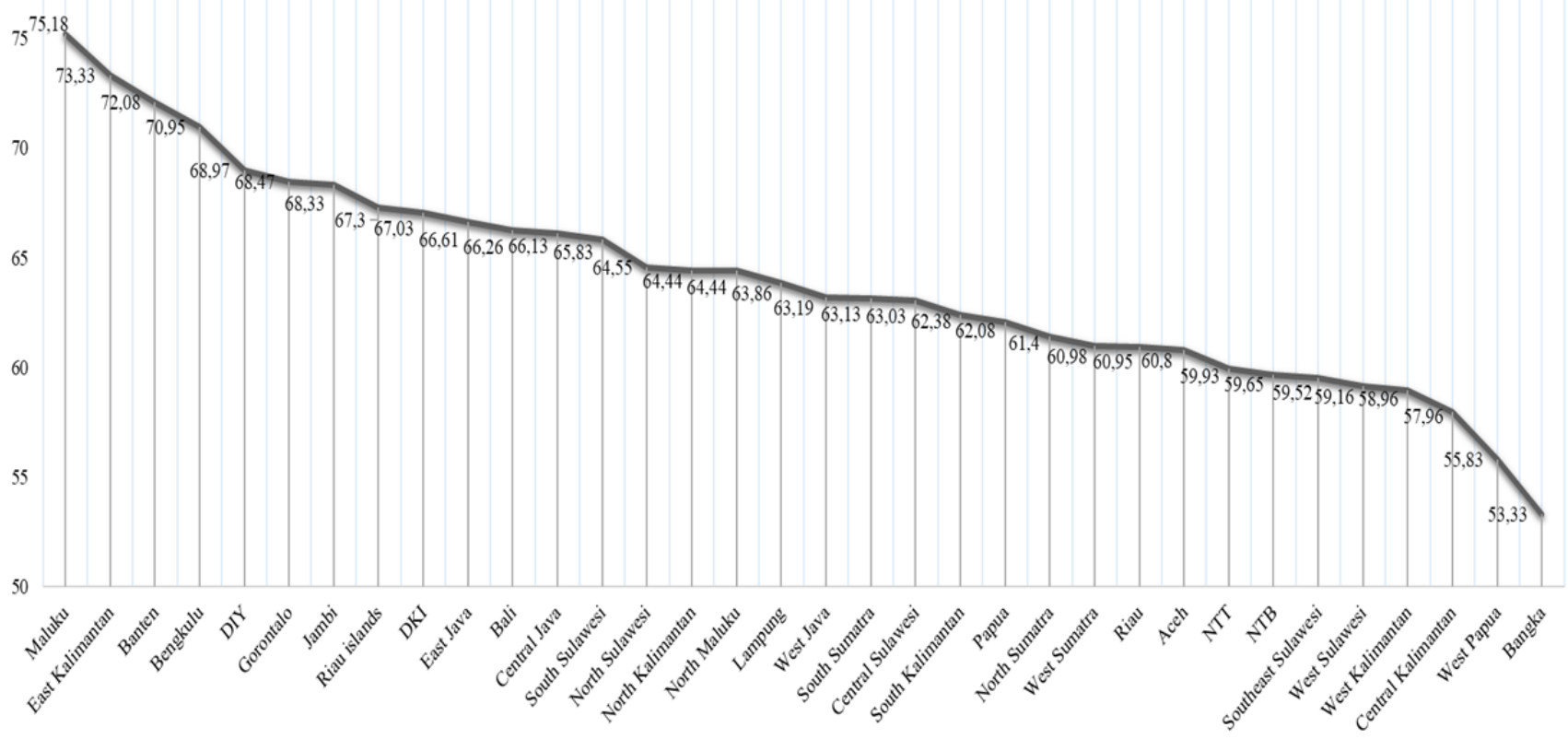

Figure 3. Distribution of Environmental Turbulence in the 21st Century in Each Province

The graph in Figure 3 shows that Maluku is the readiest compared to other VHS in facing environmental turbulence. Researchers assume that the province has few strategic development issues so that the turbulence affected is minimal. The data above shows that the distribution of turbulence is quite evenly distributed in various islands. It shows that the acceptability of VHS by external factors faced by schools varies in variety and response in anticipation. The movement of the graph to the left and the lower scoring indicates that VHS is not ready to face the turbulence of the 21st Century environment. The unpreparedness is due to the unpredictable strategies and conditions of schools, inadequate supporting facilities or infrastructure, and human resources disrupted by external obstacles [15].

The environmental turbulence study also compared VHS responses with both public and private status. The difference in school responses is quite slight between the two school statuses. In terms of the average percentage, VHS with public status is better prepared than VHS with private status. The reason for the high public VHS readiness for the 21st Century environmental turbulence is having a lot of government program assistance in overcoming external barriers to management. Changes in direction and policies experienced by domestic VHS are something that often happens, so they quickly predict changes in direction and internal policies [16]. The need for educational facilities faces market demands such as the need for competency certification for public VHS graduates supported by the government and stakeholders. Also, the demands of digitizing the learning process have been facilitated by a large number of aid tools, HR development, and facility revitalization. The existence of government gaps in managing VHS in Indonesia both in quality and quantity causes different effects of turbulence. 


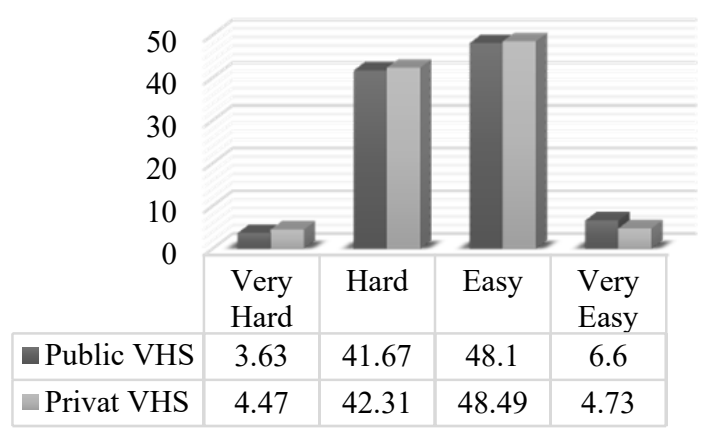

Figure 4. Comparison of 21st Century Environmental Turbulence based on School Status in Indonesia

Figure 4 shows that the difficulty of environmental turbulence in private VHS is higher than that of public VHS. The difficulty of private VHS is $46.76 \%$ higher than that of public VHS, where the percentage of difficulties is $45.3 \%$ smaller. The gradation of quality available in private VHSs causes many private VHSs to be unprepared to face environmental turbulence in the 21 st Century in terms of the policy, technology, labor market and competitiveness. As for the other facilities felt by the state VHS, the school is $1.48 \%$ superior to the private VHS. It indicates that the country's VHS has enough energy to anticipate the occurrence of turbulence that is difficult to predict and chaotic.

School accreditation becomes a benchmark in determining the best and satisfying predicate. Internationalization is a school task that has to be carried out to bring schools closer to the global community [17]. Leading schools are VHS accredited A and not excellent are accredited schools other than A. Observation of the development of turbulence in each accreditation status is carried out in a comprehensive analysis. The results of the quantitative data analysis show the following comparison chart.

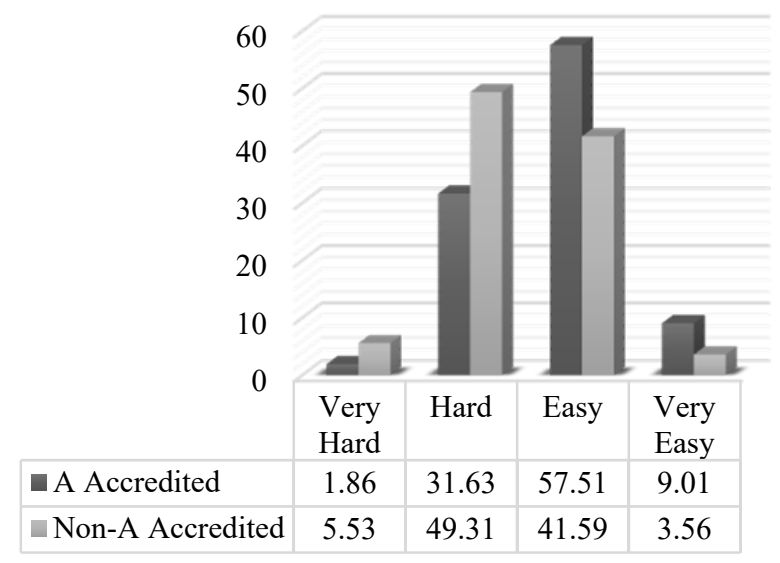

Figure 5. Comparison of 21st Century Environmental Turbulence based on School Accreditation Status in Indonesia
Comparative studies on both school statuses in Figure 5 show that VHS implementation in experiencing readiness to face environmental turbulence in VHS A accreditation is higher than non-A accreditation. The difficulty of VHS with nonA accreditation is higher with a percentage of $54.84 \%$ compared to accreditation A with a smaller percentage of difficulties of $33.49 \%$. The quality gradation shows that VHS with superior status is better prepared to face and anticipate the occurrence of environmental turbulence in the 21 st Century. Factors of readiness, completeness of facilities, quality program activities, good governance, and useful human resource input provide VHS with stronger accreditation in unpredictable changes. Educational issues that often occur in Indonesia include curriculum changes, demands for industrial competence, changes in direction and government policy [18], and other things that are short-term, medium-term and long-term changes.

\section{Conclusion}

Based on the levelling of the questionnaire distribution in 34 provinces, the following essential points were summarized:

- Nationally, VHS is quite ready to face the environmental turbulence of the 21 st Century.

- In assessing school status, public schools are better prepared than private schools in facing turbulence.

- In the accreditation ranking, schools with accreditation $\mathrm{A}$ are better prepared than those accredited in addition to $\mathrm{A}$ in facing turbulence.

The conclusions can recommend to the VHS principals that readiness to face environmental turbulence needs to be anticipated quickly and responsively. School toughness will be tested when faced with the turbulence that comes unpredictably and allows chaos. 


\section{References}

[1]. Staniec, I. (2018). Technological Entrepreneurship: How does Environmental Turbulence Impact upon Collaboration Risk?. Sustainability, 10(8), 2762.

[2]. Dewi, S., Kasali, R., Balqiah, T. E., \& Widjaja, A. W. (2017, November). The Role of Entrepreneurial Orientation in Achieving Organization Performance through Business Model Innovation And Strategic Collaboration. In International Conference on Business and Management Research (ICBMR 2017) (pp. 238-249). Atlantis Press.

[3]. Nashiruddin, M. I. (2018). Understanding the Turbulence of Business Environment in Telecom Industry: Empirical Evidence from Indonesia. Buletin Pos Dan Telekomunikasi, 16(2), 75-90.

[4]. Penc-Pietrzak, I. (2014). Competitive strategy in turbulent environment (pp. 11-12), Wolczanska: Lodz University of Technology Press.

[5]. Zemelka, G. (2016). Environmental monitoring and management-environmental engineering education at CUT Kraków, Poland. Global Journal of Engineering Education, 18(1).

[6]. Sudira, P. (2014). Indonesia vocational education praxis betwen. Empowering Vocational Education and Training to Elevate National Economic Growth, 190-200.

[7]. Ghufron, A., Suwarna, Sudiyatno, Sunarto, S., Andayani, S., Setiadi, B. R., \& Ismara, K. I. (2019). Modernisasi bengkel laboratorium kejuruan abad 21 (pp. 138-142), Jakarta: Direktorat Pembinaan Sekolah Menengah Kejuruan.

[8]. Pusca, D., \& Northwood, D. O. (2017). The why, what and how of teaching: an engineering design perspective. Global Journal of Engineering Education, 19(2), 106-111.

[9]. Felipe, C. M., Roldán, J. L., \& Leal-Rodríguez, A. L. (2017). Impact of organizational culture values on organizational agility. Sustainability, 9(12), 2354.
[10]. Bratianu, C. (2017, March). Strategic thinking in turbulent times. In Proceedings of the 11th International Conference on Business ExcellenceStrategy, Complexity and Energy in Changing Times, Bucharest University of Economic Studies, Bucharest, Romania (pp. 248-254). https://doi.org/10.1515/picbe-2017-0026. Sciendo.

[11]. School Development Division. (2010). Good governance quality education (pp. 1-2).

Retrieved from:

http://www.edb.gov.hk/attachment/en/schadmin/sbm/corner-imc-sch/good\%20governance.pdf [accessed: 09 July 2021].

[12]. Kipley, D., Lewis, A., \& Jewe, R. (2012). Entropydisrupting Ansoff's five levels of environmental turbulence. Business Strategy Series, 13(6), 251-262. https://doi.org/10.1108/17515631211286083.

[13]. Ansoff, H. I., \& Sullivan, P. A. (1993). Optimizing profitability in turbulent environments: A formula for strategic success. Long range planning, 26(5), 11-23. https://doi.org/10.1016/0024-6301(93)90073-O.

[14]. Pinsonneault, A., \& Kraemer, K. (1993). Survey research methodology in management information systems: an assessment. Journal of management information systems, 10(2), 75-105. https://doi.org/10.1080/07421222.1993.11518001.

[15]. Maley, J. F. (2019). Preserving employee capabilities in economic turbulence. Human Resource Management Journal, 29(2), 147-161. https://doi.org/10.1111/1748-8583.12211

[16]. Ansell, C., \& Trondal, J. (2018). Governing turbulence: An organizational-institutional agenda. Perspectives on public management and governance, 1(1), 43-57. https://doi.org/10.1093/ppmgov/gvx013.

[17]. Valiulis, A. V. (2015). Higher education internationalisation beyond 2015. Global Journal of Engineering Education, 17(2).

[18]. Estriyanto, Y., Kersten, S., Pardjono, P., \& Sofyan, H. (2017). The missing productive vocational high school teacher competency standard in the Indonesian education system. Journal of Technical Education and Training, 9(1). 